Contact with nature, connectedness, environmental identity and evocations / Contacto con la naturaleza, conectividad, identidad ambiental y evocaciones

\title{
Effects of contact with nature on connectedness, environmental identity and evoked contents / Efectos del contacto con la naturaleza en conectividad, identidad ambiental y contenidos evocados
}

\author{
Antonio Mena-García ${ }^{\mathrm{a}}$, Pablo Olivos ${ }^{\mathrm{a}}$, Ana Loureiro $\underline{\mathrm{b}}$ and Oscar Navarro \\ ${ }^{a}$ Universidad de Castilla-La Mancha; ${ }^{b}$ Universidade Lusófona, HEI-Lab; ${ }^{C}$ Université de Nantes
}

(Received 20 April 2018; accepted 11 July 2019)

Translated from Spanish / Traducción del español: Anna Moorby

Authors' Address / Correspondencia con los autores: Antonio Mena-García, Universidad de CastillaLa Mancha, Facultad de Relaciones Laborales y Recursos Humanos, Plaza de la Universidad 1, Albacete 02071, España. E-mail: Antonio.Mena@alu.uclm.es

\begin{abstract}
Natural experiences influence identity and the way of interacting with the environment, and their effects are varied, including well-being and positive thoughts towards nature. This study analyses the effects produced as a result of real or virtual experiences of nature. A total of 288 people took part in this research, distributed among three experimental conditions: nature walk, images of nature and control group. Changes were registered in terms of connectedness and environmental identity, caused by the experimental conditions and differences in the free evocations generated. Connection to nature was higher among those who took part in the nature walks, related to the evocation of positive emotions, memories of social experiences in nature and pro-environmental reflections. These results are interesting for the field of environmental education and the promotion of environmental values and behaviours.
\end{abstract}

Keywords: connectedness to nature; environmental identity; well-being; memories; natural elements

Resumen: Las experiencias naturales influyen en la identidad y en el modo de relacionarse con el medioambiente, y sus efectos son variados, incluyendo el bienestar y los pensamientos positivos hacia la naturaleza. Este estudio analiza estos efectos como resultado de experiencias naturales reales o virtuales. Participaron 288 personas, distribuidas en tres condiciones: recorrido natural, visualización de imágenes naturales, y grupo control. Se registraron cambios en conectividad con la naturaleza e 
identidad ambiental producido por las condiciones, y diferencias en las evocaciones libres producidas. El sentimiento de conexión a la naturaleza es superior en los recorridos, y está relacionado con la evocación de emociones positivas, de recuerdos de experiencias sociales en la naturaleza, y de reflexiones pro-ambientales. Estos resultados son interesantes para el ámbito de la educación ambiental y de la promoción de valores y comportamientos ambientales.

Palabras clave: conectividad con la naturaleza; identidad ambiental; bienestar; recuerdos; elementos naturales.

\section{Connectedness to nature and environmental identity $<<t /$ s: Head1 $>>$}

Studies on identity and the environment have observed that the self bears a close relationship with different types of positive dispositions towards the environment (Arnocky, Stroink, \& DeCicco, 2007; Hoot \& Friedman, 2011; Olivos \& Aragonés, 2013). A vast array of variables have been postulated to study this relationship of connection to nature (for a review, see Brügger, Kaiser, \& Roczen, 2011; Capaldi, Dopko, \& Zelensk, 2014; Ives et al., 2017; Tam, 2013). Connectedness to nature, one of the most frequently used concepts, evaluates individual affective experience of feeling a bond with nature (Mayer \& Frantz, 2004), and it is formulated on the basis of a biophilic foundation that attributes to human beings an innate predisposition to feel an affiliation with the natural elements (Wilson, 1984). Although questions have been raised regarding the affective nature of the construct to describe it principally as a cognitive element (Perrin \& Benassi, 2009), along with the validity and reliability of its scale (Pasca, Aragonés, \& Coello, 2017), there is consensus that the original scale possesses a single underlying factor and good internal consistency (Mayer \& Frantz, 2004; Navarro, Olivos, \& Fleury-Bahi, 2017). Various studies have shown that connectedness is related to environmental attitudes (e.g., Olivos, Aragonés, \& Amérigo, 2011), pro-environmental behaviour (e.g., Frantz \& Mayer, 2014) and well-being (e.g., Howell, Dopko, Passmore, \& Buro, 2011).

From another perspective, taking a social approach, Clayton (2003, 2012) analyses the construction of identity that revolves chiefly around the environment. The concept of Environmental Identity was proposed as a type of social identity encompassing several dimensions related to nature (Clayton, 2003): interaction, importance, affiliation and positive emotions towards it. Olivos and Aragonés (2011) identified four underlying dimensions to the scale created by Clayton: environmental identity (similar to connectedness), enjoyment of nature, appreciation of nature and environmentalism.

\section{Natural experiences and connection to nature $<<t / s:$ Head1 $>>$}

Connection to nature is sensitive to experiences with nature. An increase has been observed in levels 
of connection after participating in different types of nature activities, such as stays in or walks around natural areas (e.g., Liefländer, Fröhlich, Bogner, \& Schultz, 2013; Olivos, Aragonés, \& Navarro, 2013; Schultz \& Tabanico, 2007). However, little research has examined in depth the factors that contribute to this. Furthermore, there is extensive evidence about the positive effects of contact with natural environments on people's health and well-being (e.g., Kaplan, 2001, 1995; Staats, Gatersleben, \& Hartig, 1997), and connection to nature can play a mediating role in enhancing positive moods derived from these experiences (Mayer, Frantz, Bruehlman-Senecal, \& Dolliver, 2009), or it can be fostered by the emotions experienced in natural environments (Wyles et al., 2017).

Another point of interest in relation to natural experiences are the evocations, meanings and thoughts that emerge during them. Schroeder $(1991,2002, \underline{2007)}$ asked people who feel an attraction towards outdoor spaces to describe their favourite place and to write down their thoughts, sensations, memories and experiences related to that place. The descriptions given contained recurrent themes in relation to the beauty, admiration, tranquillity and naturalness of the places, to the emotions experienced in them, as well as the feelings of refuge and escape, and to the social sphere, such as family bonds and experiences. In some cases, personal experience with the place gave participants a sense of connection to nature, of feeling included in the natural order of the environment. Other thoughts expressed the idea that nature and human civilization are separate and in confrontation, together with the personal need to get away from the city and from other people. Thomashow (1995), conducting research with participants from different natural environments around the world (Asia, Europa, Africa and the Americas), found similar emotional and family experiences in the contents of evocations about those environments. Olivos et al. (2013), in a study in which the participants went on a nature walk, compiled from among the evocations triggered by the activity a large number of memories of nature experiences taken from the participants' childhood ( $24 \%$ of the evocations registered), as well as similar contents to those mentioned earlier. However, there is no information about the possible relationship these perceptions, sensations and thoughts might have with connection to nature.

\section{Research approach $<<\mathrm{t} / \mathrm{s}:$ Headl $>>$}

With this background, a study was conducted with the primary goal of analysing the relationships between the types of thoughts evoked and connection to nature during nature experiences, in which we expected to find an increase in the sense of connection that could be characterized through evocations characteristic of connection to nature. To produce these situations of connection, two types of activities were carried out: viewing images of nature and taking part in nature 
walks. Meanwhile, to evaluate connection to nature, two variables were used: connectedness and environmental identity. The specific objectives were:

- To describe the effects of each type of activity on connectedness and environmental identity. As in other studies, we expected connection to nature to increase following contact with nature (e.g., Mayer et al., 2009; Schultz \& Tabanico, 2007), although in this study we could also compare whether the effect is the same in the two connection variables and after the two types of activities.

- To characterize and compare activities according to the contents evoked afterwards. The contents should be similar to those found in previous studies (Olivos et al., 2013; Schroeder, 2007; Thomashow, 1995).

- Finally, tying in with the previous points, to analyse the relationship between the contents evoked and the connection registered after the activities. Participants who report a greater connection should evoke positive qualities such as beauty, tranquillity, positive emotions, personal memories and/or agreeable thoughts, respect or identification with the natural world.

Method

Design

In order to compare and contrast the effects of nature activities on connection, a pre-test/post-test design was used, measuring the impact of nature on connection as the difference between a baseline evaluation and a measurement taken immediately after the activities. In addition to the experimental conditions pertaining to exposure to nature, a control condition was created in which the participants were not exposed to any nature stimulus.

This research sets out data compiled in three different countries. The original study was conducted in Spain, and subsequently replicated in France and Portugal under similar but not identical conditions, with variations in the natural environments experienced in each country, which will be discussed later and which, far from altering the main objective of this research project as a whole, broadened its perspectives. Hence, the data set compiled was larger, but it was not felt that the effect of the activities on the connection felt with nature should vary substantially as a result of the provenance of the participants, in accordance with studies carried out in different western countries that report similar effects for nature experiences on connection (e.g., Liefländer et al., 2013; Olivos et al., 2013; Schultz \& Tabanico, 2007). However, to verify this as far as possible, the country factor was taken into consideration in the analyses carried out.

\section{Participants}

A total of 288 people took part, the large majority of whom were university students: $54.2 \%$ Spanish,

19.1\% French and $26.7 \%$ Portuguese. They were all selected using convenience sampling. The 
number of participants varied in each country, with a larger number surveyed in the original study (Spain) than in the replications, on account of the academic calendar and access to the student population in accordance with the fieldwork calendar established, which sought to control for other environmental variables, such as the climate, for example, and to avoid student mobilizations in any of the participant countries. The nature walk groups were smaller in size owing to the logistical difficulties of transporting the participants, whilst maintaining a similar size between the countries, of approximately 15 participants. In total, in the nature walk group there were 48 participants (14 Spanish, 18 Portuguese and 16 French; $M=22.9$ years of age; $66.7 \%$ women); 120 in the images group (60 Spanish, 40 Portuguese and 20 French; $M=27.7$ years of age; $73.3 \%$ women); and 120 in the control group (82 Spanish, 19 Portuguese and 19 French; $M=24.1$ years of age; $72.5 \%$ women).

\section{Instruments}

In the pre-test and post-test data-gathering exercises, a self-administered questionnaire was used, containing the following scales, adapted to the official language of each country:

The Connectedness to Nature Scale (CNS) by Mayer and Frantz (2004), adapted into Spanish by Olivos et al. (2011), into French by Navarro et al. (2017) and into Portuguese by Loureiro, Olivos, and Navarro (2014). It contains 14 items with five-point Likert type responses (1=|'strongly disagree'; $5=$ ='strongly agree'). The reliability of the scales for the pre-rest $(\alpha$ range $=.79-.86)$ and post-test ( $\alpha$ range $=.77-.88$ ) application was satisfactory, with normal distributions (maximum asymmetry $=-1.06$; maximum kurtosis $=1.1$ ).

The Environmental Identity Scale (EID), developed by Clayton (2003), was adapted into Spanish (Olivos \& Aragonés, 2011), French (Navarro et al., 2017) and Portuguese (Loureiro \& Olivos, 2017). It contains 24 items, with five-point Likert type responses $(1=$ 'strongly disagree'; $5=$ 'strongly agree'). The versions yielded high levels of reliability in the pre-test ( $\alpha$ range $=.9-.92)$ and post-test $(\alpha$ range $=.9-.92)$ applications, with normal distributions (maximum asymmetry $=-0.9$; maximum kurtosis $=1.27$ ).

In the post-test surveys of the participants who had been exposed to nature, two additional open-ended questions were added, aimed at compiling, respectively, a description of the natural elements observed and the evocations (emotions, sensations, memories, etc.) that emerged after the two conditions, in line with previous studies (Olivos et al., 2013; Schroeder, 2007).

\section{Natural stimuli}


With regard to the groups that viewed images of nature, the same set of 30 photographs was used in all three countries surveyed, depicting natural landscapes, plants and animals, used previously by Sánchez, de la Garza, and López (2010). They contained landscapes of different natural environments (fields, forest, deserts) and close-ups of wild animals (shark, tiger, insects) and plants (fungi, cacti, flowers ...).

For the nature walks, although efforts were made to ensure that some of the elements would be similar, such as diverse flora (plants, bushes and trees), small wildlife (particularly birds) and water (ponds or rivers), for logistical reasons, equivalent but different natural environments were used. In the Spanish fieldwork conducted, the participants walked around a wild natural environment, by a lake situated in the open countryside, which offered a high level of immersion in nature; in the other two, natural urban environments of varying size were used. The French group walked around an urban park that featured a small river and plenty of vegetation characteristic of Bretagne, thus provoking a lower level of natural immersion than in the case of Spain; and in Portugal, a smaller and open urban park, located close to a major avenue, with trees, landscaped areas and a pond, offering the lowest level of immersion of the three nature walks. In relation to these differences between the environments experienced, some authors have found different effects on connection to nature and well-being, depending on whether the environment is one of wild nature or urban nature (e.g., Davis \& Gatersleben, 2013; Hinds \& Sparks, 2011; Wyles et al., 2017), and also that the same type of natural environment can give rise to different effects depending on its specific elements and biodiversity (e.g., Carrus et al., 2015; Chiang, Li, \& Jane, 2017; Hoyle, Hitchmough, \& Jorgensen, 2017; Southon, Jorgensen, Dunnett, Hoyle, \& Evans, 2017). Hence, the differences between natural environments could imply differences in the effects observed. However, the recording of evocations and their relationship with the types of environment and connection may help to explain these possible differences, adding further value to this research.

\section{Procedure}

All the participants in the study were evaluated in a classroom situation using the pre-test questionnaire two weeks before taking part in their corresponding nature activities. The participants in the images groups looked at nature photographs projected in different classrooms. Each photograph was shown for five seconds, with no break between them, and in a previously established random order, identical for all participants and countries. After they had seen all the images, the participants completed the post-test questionnaire. The participants in the nature walks groups were driven to the nature environment locations. The walks were carried out around accessible areas in these 
environments and lasted around 20 minutes. During the walks, the participants were asked to observe the environment and finish up with 10 minutes of individual contemplation. Subsequently, they were given the post-test self-administered questionnaire. The participants in the control group were evaluated once again in a classroom setting, two weeks after the initial evaluation. The application of each questionnaire $—$ pre and post-test $—$ took approximately 20 minutes.

\section{Data processing}

In order to analyse the effect of experiences on connection to nature, a repeat measures ANOVA was conducted using SPSS24 software, including as a variable the participants' country of origin in order to detect differences between the samples. Effect size was calculated (ES, by means of the $f$ statistic) along with statistical power $(S P)$ using the $\mathrm{G}^{*}$ Power 3.1 program (Faul, Erdfelder, Lang, \& Buchner, 2007). Castro and Martini (2016), using consensus values, determined that $E S$ is small when $f$ reaches the value of .1, medium at around .25 and large from .4 upwards. As for $S P$, adequate values are around .8, considering that lower values imply risks of not detecting differences (type II error).

The open-ended answers in French and Portuguese were translated into Spanish using backtranslation with native speakers to confirm their correct sense and meaning. Subsequently, all the responses were subjected to content analysis, following the open coding procedure of identifying units of analysis (Strauss \& Corbin, 1994). Each open-ended response was broken down into propositions or units of analysis, consisting of words or small phrases that contained the lowest possible unit of meaning that made sense. A proposition was constituted when: a clear meaning that made sense was found; the following terms changed object or action; there were punctuation marks that indicated a pause (full stops and non-enumerative commas). Many of the propositions contained more than one relevant meaning to the research goals, and therefore each proposition could be classified in more than one content category. In total, 961 propositions were found. To establish the categories used to classify meanings, those used in similar environmental studies were taken as a reference (Galindo \& Corraliza, 2000; Kaplan, 2001; Olivos et al., 2013; Schroeder, 1991). Based on these, an inductive process was then followed, in which some categories were merged, subdivided or eliminated. New categories were also created according to the requirements of the classification process. A total of 32 categories were identified: 18 associated with responses from the two nature activities groups, and 14 exclusive ones for each group (detailed in Table 3).

To characterize the different nature activities according to the evocations recorded, the reporting frequencies of the categories in each group were calculated. Furthermore, Chi-square 
analyses were carried out $\left(X^{2}\right)$ in the common categories to the groups in order to observe differences and similarities between the evocations generated after experiences with nature.

In order to analyse which evoked contents were linked with a greater feeling of connection, one-way ANOVA tests were carried out to compare, in each content category, the levels of connection felt by the participants who reported the content with those who did not. Separate analyses were carried out for each activity, given that the same element can vary its effect depending on the type of exposure. $E S$ and $S P$ were calculated in order to interpret the significant differences found.

\section{Results}

\section{Effect of nature experiences on CNS and EID}

The table below sets out the results of the intra-subject effects extracted from the ANOVA tests, effect size and the statistical power of the analyses ([AQ1]Table 1):

The participants who viewed images of nature did not increase their scores on the CNS, but they did on the EID scale, with a medium ES. There was no effect observed for the country factor for either variable, since they all reflected an increase in environmental identity. The participants who went on nature walks did increase their scores for both variables, but the effect was different according to the country. The control group displayed a decline in CNS scores in all the samples. Given that the effect on connection was different depending on the country, a repeat measures ANOVA model was executed for each country separately. The results were as follows ([AQ2]Table 2):

In the Spanish group, walking around an environment that offered a high level of immersion in nature produced a major increase in both connection variables, as reflected in the ES. Differences did not achieve statistical significance in the nature walks conducted in France or Portugal, although in the French case increases were seen with regard to connection, with a medium-large ES and marginal significance in EID.

\section{Descriptions and evocations reported in nature activities}

Table 3 details the significance levels registered for each content category and the reporting frequencies of each nature activity, and compares the percentages between the groups.

The participants who were shown images used more general descriptions of nature. Animals were mentioned more in the images group, whereas flora and water were more present in the evocations triggered by the nature walks. Sensitive and atmospheric elements, which are hard or even impossible to perceive through images, were reported after the nature walks. The two groups appreciate the beauty of the stimuli, but with much more frequency in the images groups. 
In the affective sphere, relaxation appears more frequently after the nature walks. In general, these emotions and well-being are more frequently reported than activation emotions. Disconnection from the daily environment and routine establish another difference between the two groups, and is relevant in the nature walks group. Although not very frequent, negative emotions towards certain natural stimuli were only reported in the images group.

Reflections on nature were not reported very regularly in the nature walks group, and were more characteristic in the images group. Finally, childhood memories and socio-family experiences were evoked more frequently in the nature walks group.

\section{Descriptions and evocations reported in each nature walk}

Given the different effects found between the different walks, the previous analyses were repeated in order to compare the frequencies of content evocations and observe which factors could be involved in the differences observed ([AQ3]Table 4).

There were significant differences in the reporting frequencies of several categories that coincide with the differences in the effects of the nature walks on the sense of connection experienced. Hence, there were more reports of all kinds of natural elements in the Spanish sample, fewer in the Portuguese sample, with the French sample producing intermediate reporting frequencies. States of relaxation were reported frequently for all the nature walks, although less so in the walk with the lowest level of immersion in nature. States of activation do not appear to be relevant, whereas reports of well-being and disconnection were more habitual in the Spanish sample, followed by the French sample and finally the Portuguese sample. Urban elements were practically non-existent in the Spanish nature walk. The evocation of activities carried out was greater in the Portuguese group, but the enjoyment of activities in nature yielded a stepped pattern from higher to lower levels of immersion in nature, as did reflections and thoughts of nature.

\section{Relation between connection to nature and reported descriptions and evocations}

In the groups that were shown images of nature, the one-way ANOVA tests performed to compare the levels of connection between the participants according to the contents they generated for each category (for all reported $F: d f=1,117$ ) showed that only those who indicated that they felt an identification with the natural stimuli showed significantly higher levels of EID $(F=4.491 ; p=.036$; $f=.154 ; S P=\mid .384)$. Marginally higher scores were also recorded for those who generated metapersonal and spiritual reflections $(F=3.83 ; p=.053 ; f=.18 ; S P=.492)$ and those who highlighted the beauty of the images $(F=3.01 ; p=.08 ; f=.35 ; S P=.404)$. 
For the participants who went on nature walks, the ANOVA tests conducted (for all reported $F$ : $d f=1,45)$ revealed that those who described elements of flora obtained higher scores on the EID scale $(F=4.663 ; p=.036 ; f=.314 ; S P=.558)$. Those who mentioned atmospheric elements obtained higher scores on the CNS $(F=4.473 ; p=.04 ; f=.312 ; S P=.514)$ and EID scales $(F=6.101$; $p=.017 ; f=.321 ; S P=.537$ ), as did those who named sensitive characteristics (CNS, $F=9.139$; $p=.004 ; f=.446 ; S P=\mid .824 ;$ EID,$F=4.652 ; p=.036 ; f=.318 ; S P=.569)$. Reporting sensations of well-being was related to higher scores on the EID scale $(F=5.391 ; p=.025 ; f=.344 ; S P=.637)$. The tendency to recount the activities carried out during the experience was registered among participants with a lower score on the CNS $(F=4.858 ; p=.033 ; f=.325 ; S P=.587)$. Although there were not many reflections on nature in this group, the few participants that did express them showed greater connection, as highlighted by the differences in their identifications with nature (EID, $F=6.291 ; p=.016 ; f=.37 ; S P=.7)$, environmental concerns $(\mathrm{CNS}, F=4.676 ; p=.036 ; f=.319$; $S P=.572 ; \mathrm{EID}, F=6.71 ; p=.013 ; f=.382 ; S P=.727)$ and meta-personal reflections (EID, $F=5.38$; $p=.025 ; f=.342 ; S P=.632$ ). Finally, participants who evoked socio-family memories showed greater connection $(\mathrm{CNS}, F=4.879 ; p=.032 ; f=.325 ; S P=.588 ; \quad$ EID,$F=5.896 ; p=.019 ; f=.359$; $S P=.673)$, as did, albeit marginally, those who mentioned memories of other experiences with nature (CNS, $F=3.808 ; p=.057 ; f=.288 ; S P=.49)$.

\section{Discussion and conclusions}

Connection to nature increases when an individual is in contact with nature. Given its relationship with the self and identity, one might expect to find great stability in this concept. However, there is enough evidence about the contextual sensitivity of the self (e.g., [AQ4]Kashima et al., 2002), and its relationship with the environment (e.g., Arnocky et al., 2007), as well as the increase in connection after coming into contact with nature (e.g., Mayer et al., 2009; Schultz \& Tabanico, 2007). When exposed to the same stimuli (images), all the participants experienced a similar effect on their environmental identity; hence the effect of nature activities does not seem to be influenced by the origin of the participants. This aspect is important in the discussion of the results observed in the nature walks, since differences were found in the effects reported between the different studies. As mentioned previously, this is probably due to the type of natural environment and the level of immersion in nature. The absence of the country factor effect on the results of the images group supports this hypothesis. The effect of the nature walk that afforded participants a greater level of immersion in nature on their connection was so high that the analyses reflected significant results in 
spite of the small size of the group. This aspect makes it difficult to achieve adequate statistical significance for the effect of the French nature walk, which offered a medium level of immersion in nature, the results of which possess a notable effect size, albeit it smaller than in the Spanish group. With regard to the comparison of effects between the types of activities and connection, nature walks are richer experiences, affecting both types of connection. Images of nature provoke a more subtle stimulation, linked to a non-biophilic aspect of environmental identity, a more heterogeneous variable than connectedness (Olivos \& Aragonés, 2011).

Evocations offer a better understanding of the different effects of activities. The nature walks constituted the most intense experiences on a sensitive and perceptive level, especially at greater levels of natural immersion in the environment. The way in which its elements, principally the sensitive and atmospheric elements (Franco, Shanahan, \& Fuller, 2017), are experienced can be relevant from a biophilic perspective, as shown by the relationship between the reporting of these contents and the greater connection felt. Experiences of real contact are more easily able to generate positive affective states, generally of relaxation and restoration, which are more marked the greater the level of immersion in nature. The reporting of well-being in these experiences bears a close relationship with connection, as many researchers have reported (e.g., Mayer et al., 2009; Wyles et al., 2017). Disconnection from the urban sphere could be another key factor to explain the differences between the different environments. Although following the nature walks there were very few environmentalist reflections generated, they are related to greater connection. Experiences with images, on the other hand, did facilitate these kinds of thoughts, which are relevant for the formation of pro-environmental attitudes. These contents, together with positive aesthetic appreciations of nature, are reported by participants with greater levels of connection after viewing the images; hence, it would be advisable to foster such aspects in experiences conducted with these stimuli.

The contents registered also included memories and experiences of contact with nature from early childhood or adolescence, with close relatives or groups of important friends, similar to those obtained by Schroeder (2007) and Thomashow (1995). These early experiences with nature play an important role (e.g., Chawla \& Cushing, 2007; Davis, Rea, \& Waite, 2006; Wells \& Lekies, 2006), as shown by the relationship between memories of nature, experienced with important social figures, and connection to nature. The evocation of these contents during nature walks denotes the impact of these experiences in childhood and adolescence, and suggests that environmental education activities could be planned around the effects of contact with nature in order to develop positive and long-lasting ecological identities at these ages. 
There are certain limitations to be taken into consideration, owing mainly to the compilation of data in three different contexts and the logistical difficulties of carrying out the nature walks, which gave rise to a low number of participants in certain conditions and a certain inequality of size between the groups. However, all the response distributions described normal patterns; the assumptions of homoscedasticity and sphericity in the ANOVA models were fulfilled; and, furthermore, statistics were provided for effect size, which helped to compensate for the dependence of the $p$ statistic in relation to sample size (Castro \& Martini, 2016; Cohen, 1994). Furthermore, the main limitation of this study lies in the difficulty with controlling the experimental conditions of the nature walk groups, where the country factor cannot be separated from the level of immersion in nature afforded by the environment. However, the effects of contact with nature on connection have been observed in a similar way in different countries and contexts (e.g., Liefländer et al., 2013; Olivos et al., 2013; Schultz \& Tabanico, 2007), whereas there is evidence of different effects according to the type of natural environment, its elements and its biodiversity (e.g., Chiang et al., 2017; Davis \& Gatersleben, 2013; Southon et al., 2017). Hence it is reasonable to point to the difference in the levels of immersion in nature as being the main factor responsible for the different effects found among the nature walks. The procedure and the data offer evidence and perspectives to guide other studies aimed specifically at the type of contents that have emerged in this research as being relevant.

In short, connectedness and environmental identity are affected by experiences of coming into contact with nature, particularly on account of certain natural elements, feelings of well-being, certain natural and meta-personal reflections, and socio-affective memories.

\section{Disclosure statement[AQ5]}

No potential conflict of interest was reported by the authors.

\section{Supplemental material}

The Spanish version of this article is available only as online supplementary material here $<<\mathrm{t} / \mathrm{s}$ : link >>. / La versión en castellano de este artículo está disponible únicamente como material suplementario online aqui $<<t / s$ : link $>>$.

\section{References / Referencias[AQ6]}

Arnocky, S., Stroink, M., \& DeCicco, T. (2007). Self-construal predicts environmental concern, cooperation, and conservation. Journal of Environmental Psychology, 27, 255-264.

Brügger, A., Kaiser, F. G., \& Roczen, N. (2011). One for all? Connectedness to nature, inclusion of nature, environmental identity, and implicit association with Nature. European Psychologist, 16, 324 333. 
Capaldi, C. A., Dopko, R. L., \& Zelensk, J. M. (2014). The relationship between nature connectedness and happiness: A meta-analysis. Frontiers in Psychology, 5, 976.

Carrus, G., Scopelliti, M., Lafortezza, R., Colangelo, G., Ferrini, F., Salbitano, F., ... Sanesi, G.

(2015). Go greener, feel better? The positive effects of biodiversity on the well-being of individuals visiting urban and peri-urban green areas. Landscape and Urban Planning, 134, 221-228.

Castro, J. M. C., \& Martini, H. A. (2016). Potencia estadística y cálculo del tamaño del efecto en G* Power: Complementos a las pruebas de significación estadística y su aplicación en psicología. Salud \& sociedad, 5(2), 210-244.

Chawla, L., \& Cushing, D. F. (2007). Education for strategic environmental behaviour. Environmental Education Research, 13(4), 437-452.

Chiang, Y. C., Li, D., \& Jane, H. A. (2017). Wild or tended nature? The effects of landscape location and vegetation density on physiological and psychological responses. Landscape and Urban Planning, 167, 72-83.

Clayton, S. (2003). Environmental identity: A conceptual and an operational definition. In S. Clayton $\&$ S. Opotow (Eds.), Identity and the natural environment. The psychological significance of nature (pp. 45-65). Cambridge: The MIT Press.

Clayton, S. (Ed.). (2012). Handbook of environmental and conservation psychology. New York: Oxford University Press.

Cohen, J. (1994). The earth is round $(p<.05)$. American Psychologist, 49, 997-1003.

Davis, B., Rea, T., \& Waite, S. (2006). The special nature of the outdoors: Its contribution to the education of children aged 3-11. Journal of Outdoor and Environmental Education, 10(2), 3-12.

Davis, N., \& Gatersleben, B. (2013). Transcendent experiences in wild and manicured settings: The influence of the trait "connectedness to nature". Ecopsychology, 5(2), 92-102.

Faul, F., Erdfelder, E., Lang, A. G., \& Buchner, A. (2007). G* Power 3: A flexible statistical power analysis program for the social, behavioral, and biomedical sciences. Behavior Research Methods, 39(2), 175-191.

Franco, L. S., Shanahan, D. F., \& Fuller, R. A. (2017). A review of the benefits of nature experiences: More than meets the eye. International Journal of Environmental Research and Public Health, 14(8), 864. 
Frantz, C. M., \& Mayer, F. S. (2014). The importance of connection to nature in assessing environmental education programs. Studies in Educational Evaluation, 41, 85-89.

Galindo, M. P., \& Corraliza, J. A. (2000). Environmental aesthetics and psychological well-being. Psychology in Spain, 4(1), $13-27$.

Hinds, J., \& Sparks, P. (2011). The affective quality of human-natural environment relationships. Evolutionary Psychology, 9(3), 147470491100900314.

Hoot, R. E., \& Friedman, H. (2011). Connectedness and environmental behavior: Sense of interconnectedness and pro-environmental behavior. International Journal of Transpersonal Studies, 30, 89-100.

Howell, A. J., Dopko, R. L., Passmore, H. A., \& Buro, K. (2011). Nature connectedness: Associations with well-being and mindfulness. Personality and Individual Differences, 51(2), 166-171.

Hoyle, H., Hitchmough, J., \& Jorgensen, A. (2017). All about the "wow factor'? The relationships between aesthetics, restorative effect and perceived biodiversity in designed urban planting. Landscape and Urban Planning, 164, 109-123.

Ives, C. D., Giusti, M., Fischer, J., Abson, D. J., Klaniecki, K., Dorninger, C., ... von Wehrden, H. (2017). Human-Nature connection: A multidisciplinary review. Current Opinion in Environmental Sustainability, 26-27, 106-113.

Kaplan, R. (2001). The nature of the view from home psychological benefits. Environment and Behavior, 33, 507-542.

Kaplan, S. (1995). The restorative benefits of nature: Toward an integrative framework. Journal of Environmental Psychology, 15, 169-182.

Kashima, Y., Kashima, E., Farsides, T., Kim, U., Strack, F., Werth, L., \& Yuki, M. (2002). Culture and context-sensitive self: The amount and meaning of context-sensitivity of phenomenal self differ across cultures. Self and Identity, 3(2), 125-141.

Liefländer, A. K., Fröhlich, G., Bogner, F. X., \& Schultz, P. W. (2013). Promoting connectedness with nature through environmental education. Environmental Education Research, 19, 370-384.

Loureiro, A., \& Olivos, P. (2017, September). The role of environmental values, environmental identity, and contact with nature, in predicting support for pro-environmental behaviours. Paper presented at International Conference on Environmental Psychology, A Coruña, Spain. 
Loureiro, A., Olivos, P., \& Navarro, O. (2014, September). Contacto com ambiente natural, ligação à natureza e bem-estar. Paper presented at IX Congresso Iberoamericano de Psicologia/II Congresso Ordem dos Psicólogos Portugueses, Lisboa, Portugal.

Mayer, F. S., \& Frantz, C. M. (2004). The connectedness to nature scale: A measure of individuals' feeling in community with nature. Journal of Environmental Psychology, 24, 503-515.

Mayer, F. S., Frantz, C. M., Bruehlman-Senecal, E., \& Dolliver, K. (2009). Why is nature beneficial? The role of connectedness to nature. Environment and Behavior, 41, 607-643.

Navarro, O., Olivos, P., \& Fleury-Bahi, G. (2017). Connectedness to nature scale: Validity and reliability in the French context. Frontiers in Psychology, 8, 2180.

Olivos, P., \& Aragonés, J. I. (2011). Psychometric properties of the environmental identity scale (EID). Psyecology, 2, 65-74.

Olivos, P., \& Aragonés, J. I. (2013). Medio ambiente, self y conectividad con la naturaleza. Revista Mexicana de Psicología. En prensa.[AQ7]

Olivos, P., Aragonés, J. I., \& Amérigo, M. (2011). The connectedness with nature scale and its relationship with environmental beliefs and identity. Internacional Journal of Hispanic Psychology, 4, 5-19.

Olivos, P., Aragonés, J. I., \& Navarro, O. (2013). Educación ambiental: Itinerario en la naturaleza y su relación con conectividad, preocupaciones ambientales y conducta. Revista Latinoamericana de Psicología, 45(3), 501-511.

Pasca, L., Aragonés, J. I., \& Coello, M. T. (2017). An analysis of the connectedness to nature scale based on item response theory. Frontiers in Psychology, 8, 1330.

Perrin, J. L., \& Benassi, V. A. (2009). The connectedness to nature scale: A measure of emotional connection to nature? Journal of Environmental Psychology, 29, 434 440.

Sánchez, M., de la Garza, A., \& López, E. (2010, Abril). Un estudio de mediciones de actitudes implícitas hacia al medio ambiente en estudiantes de biología y psicología: ¿biofilial Revista Electrónica Psicología Científica.com, 12(21). Retrieved from

http://www.psicologiacientifica.com/mediciones-actitudes-hacia-medio-ambiente-biofilia/

Schroeder, H. W. (1991). Preference and meaning of arboretum landscapes: Combining quantitative and qualitative data. Journal of Environmental Psychology, 11, 231-248.

Schroeder, H. W. (2002). Experiencing nature in special places. Journal of Forestry, 100, 8-14. 
Schroeder, H. W. (2007). Place experience, gestalt, and the human-nature relationship. Journal of Environmental Psychology, 27, 293-309.

Schultz, P., \& Tabanico, J. (2007). Self, identity, and the natural environment: Exploring implicit connections with nature. Journal of Applied Social Psychology, 37, 1219-1247.

Southon, G. E., Jorgensen, A., Dunnett, N., Hoyle, H., \& Evans, K. L. (2017). Biodiverse perennial meadows have aesthetic value and increase residents' perceptions of site quality in urban green-space. Landscape and Urban Planning, 158, 105-118.

Staats, H., Gatersleben, B., \& Hartig, T. (1997). Change in mood as a function of environmental design: Arousal and pleasure on a simulated forest hike. Journal of Environmental Psychology, 17, 283-300.

Strauss, A., \& Corbin, J. (1994). Grounded theory methodology. In N. K. Denzin \& Y. S. Lincoln (Eds.), Handbook of qualitative research (pp. 217-285). Thousand Oaks: Sage Publications.

Tam, K. P. (2013). Concepts and measures related to connection to nature: Similarities and differences. Journal of Environmental Psychology, 34, 64-78.

Thomashow, M. (1995). Ecological identity, becoming a reflective environmentalist. London: MIT Press.

Wells, N. M., \& Lekies, K. S. (2006). Increasing children's freedom of movement, and other papers. Children, Youth and Environments, 16(1), 1-24.

Wilson, E. (1984). Biophilia. Cambridge: Harvard University Press.

Wyles, K. J., White, M. P., Hattam, C., Pahl, S., King, H., \& Austen, M. (2017). Are some natural environments more psychologically beneficial than others? The importance of type and quality on connectedness to nature and psychological restoration. Environment and Behavior.

doi:10.1177/0013916517738312

Table 1, Intra-subject effects tests of the activities on connection to nature.

\begin{tabular}{|l|l|l|l|l|l|l|l|l|}
\hline $\begin{array}{l}\text { Nature } \\
\text { activity }\end{array}$ & Origin & $\begin{array}{l}\text { Sum of } \\
\text { squares }\end{array}$ & $d f$ & $\begin{array}{l}\text { Quadratic } \\
\text { mean }\end{array}$ & $F$ & Sig. & $f$ & $S P$ \\
\hline Images & CNS & 0.09 & 1 & .09 & 1.043 & .309 & .095 & .784 \\
\hline & CNS*Country & 0.106 & 2 & .053 & 0.617 & .542 & .105 & .86 \\
\hline & Error & 9.567 & 111 & .086 & & & & \\
\hline & EID & 0.505 & 1 & .505 & 11.793 & .001 & .326 & 1 \\
\hline & EID*Country & 0.065 & 2 & .033 & 0.762 & .469 & .119 & .999 \\
\hline & Error & 4.752 & 111 & .043 & & & & \\
\hline Nature & CNS & 0.249 & 1 & .249 & 4.804 & .034 & .326 & .999 \\
\hline
\end{tabular}




\begin{tabular}{|l|l|l|l|l|l|l|l|l|}
\hline $\begin{array}{l}\text { Nature } \\
\text { activity }\end{array}$ & Origin & $\begin{array}{l}\text { Sum of } \\
\text { squares }\end{array}$ & $d f$ & $\begin{array}{l}\text { Quadratic } \\
\text { mean }\end{array}$ & $F$ & Sig. & $f$ & $S P$ \\
\hline Walks & & & & & & & & \\
\hline & CNS*Country & 0.453 & 2 & .226 & 4.362 & .019 & .44 & 1 \\
\hline & Error & 2.335 & 45 & .052 & & & & \\
\hline & EID & 0.173 & 1 & .173 & 4.352 & .043 & .311 & .999 \\
\hline & EID*Country & 0.224 & 2 & .112 & 2.819 & .07 & .353 & 1 \\
\hline & Error & 1.788 & 45 & .04 & & & & \\
\hline Control & CNS & 0.399 & 1 & .399 & 6.559 & .012 & .21 & .999 \\
\hline & CNS*Country & 0.095 & 2 & .047 & 0.779 & .461 & .115 & .929 \\
\hline & Error & 7.11 & 117 & .061 & & & & \\
\hline & EID & 0.016 & 1 & .016 & 0.346 & .558 & .055 & .532 \\
\hline & EID*Country & 0.065 & 2 & .032 & 0.724 & .487 & .115 & .989 \\
\hline & Error & 5.114 & 114 & .045 & & & & \\
\hline
\end{tabular}

Table 2. Intra-subject effects test of the different nature walks on connection with nature.

\begin{tabular}{|c|c|c|c|c|c|c|c|c|}
\hline Nature walks & Origin & $\begin{array}{l}\text { Sum of } \\
\text { squares }\end{array}$ & $d f$ & $\begin{array}{l}\text { Quadratic } \\
\text { mean }\end{array}$ & $F$ & Sig. & $f$ & $S P$ \\
\hline \multirow{4}{*}{$\begin{array}{l}\text { Spain } \\
\text { (high immersion in } \\
\text { nature) }\end{array}$} & $\mathrm{CNS}$ & 0.512 & 1 & .512 & 7.081 & .02 & .739 & 1 \\
\hline & Error & 0.94 & 13 & .072 & & & & \\
\hline & EID & 0.262 & 1 & .262 & 9.587 & .009 & .858 & 1 \\
\hline & Error & 0.355 & 13 & .027 & & & & \\
\hline \multirow{4}{*}{$\begin{array}{l}\text { France } \\
\text { (medium immersion } \\
\text { in nature) }\end{array}$} & $\mathrm{CNS}$ & 0.087 & 1 & .087 & 1.859 & .193 & .352 & .997 \\
\hline & Error & 0.704 & 15 & .047 & & & & \\
\hline & EID & 0.085 & 1 & .085 & 3.797 & .07 & .503 & 1 \\
\hline & Error & 0.334 & 15 & .022 & & & & \\
\hline \multirow{4}{*}{$\begin{array}{l}\text { Portugal } \\
\text { (low immersion in } \\
\text { nature) }\end{array}$} & CNS & 0.041 & 1 & .041 & 1.007 & .33 & .243 & .847 \\
\hline & Error & 0.691 & 17 & .041 & & & & \\
\hline & EID & 0.015 & 1 & .015 & 0.226 & .641 & .115 & .184 \\
\hline & Error & 1.099 & 17 & .065 & & & & \\
\hline
\end{tabular}

Table 3. Description of content categories; reporting frequencies and differences between the groups.

\begin{tabular}{|c|c|c|c|c|}
\hline Content category & Meanings related to ... & Walks $(\%)$ & $\begin{array}{l}\text { Images } \\
(\%)\end{array}$ & $\begin{array}{l}X^{2} \\
(d f=2)\end{array}$ \\
\hline Nature & Nature in general. & 42.6 & 75.6 & $16.49 * *$ \\
\hline Flora & $\begin{array}{l}\text { Vegetation: trees, plants, flowers } \\
\ldots\end{array}$ & 46.8 & 26.9 & $6.09 *$ \\
\hline Fauna & Animals: birds, fish, frogs ... & 29.8 & 68.1 & $20.17 * *$ \\
\hline Arthropods & $\begin{array}{l}\text { Animals associated with } \\
\text { unpleasant emotions: insects, } \\
\text { scorpions ... }\end{array}$ & NA & 12.6 & - \\
\hline
\end{tabular}




\begin{tabular}{|c|c|c|c|c|}
\hline Content category & Meanings related to ... & Walks $(\%)$ & $\begin{array}{l}\text { Images } \\
(\%)\end{array}$ & $\begin{array}{l}X^{2} \\
(d f=2)\end{array}$ \\
\hline $\begin{array}{l}\text { Terrain and } \\
\text { geology }\end{array}$ & $\begin{array}{l}\text { Terrain, stones and geographic } \\
\text { accidents. }\end{array}$ & 25.5 & NA & - \\
\hline Water elements & $\begin{array}{l}\text { Water elements: lake, river, } \\
\text { water ... }\end{array}$ & 46.8 & 12.6 & $22.76^{* *}$ \\
\hline Landscapes & $\begin{array}{l}\text { Specific landscapes shown in the } \\
\text { images: forests, mountains, } \\
\text { meadows ... }\end{array}$ & NA & 16 & - \\
\hline $\begin{array}{l}\text { Atmospheric } \\
\text { elements }\end{array}$ & $\begin{array}{l}\text { Atmospheric elements or } \\
\text { climate: atmosphere, air, sun ... }\end{array}$ & 21.3 & NA & - \\
\hline $\begin{array}{l}\text { Sensitive } \\
\text { characteristics }\end{array}$ & $\begin{array}{l}\text { Characteristics of the } \\
\text { environment related to the } \\
\text { senses: smells, sounds, colours. }\end{array}$ & 21.3 & NA & - \\
\hline $\begin{array}{l}\text { Wild } \\
\text { characteristics }\end{array}$ & $\begin{array}{l}\text { Natural and wild authenticity of } \\
\text { the stimuli. }\end{array}$ & NA & 39.5 & - \\
\hline Abundant nature & $\begin{array}{l}\text { The existence of a large quantity } \\
\text { of nature. }\end{array}$ & 46.8 & NA & - \\
\hline Natural beauty & $\begin{array}{l}\text { Appreciations of the beauty of } \\
\text { nature. }\end{array}$ & 40.4 & 71.4 & $13.84 * *$ \\
\hline Positive place & $\begin{array}{l}\text { Other positive spatial } \\
\text { characteristics: space, cleanness } \\
\ldots\end{array}$ & 29.8 & NA & - \\
\hline Relaxation & $\begin{array}{l}\text { Characteristics of the stimuli that } \\
\text { induce relaxation and associated } \\
\text { emotions: calm, tranquillity ... }\end{array}$ & 74.5 & 44.5 & $12.12 * *$ \\
\hline Activation & $\begin{array}{l}\text { Characteristics that transmit } \\
\text { positive activation and associated } \\
\text { emotions: energy, revitalization } \\
\ldots\end{array}$ & 14.9 & 19.3 & 0.45 \\
\hline $\begin{array}{l}\text { Well-being and } \\
\text { fulfilment }\end{array}$ & $\begin{array}{l}\text { States of well-being, fulfilment, } \\
\text { disappearance of stress and } \\
\text { freedom }\end{array}$ & 27.7 & 37.8 & 1.53 \\
\hline Disconnection & $\begin{array}{l}\text { Disconnection from daily routine } \\
\text { and urban environment }\end{array}$ & 44.7 & 16 & $15.19 * *$ \\
\hline Biophobia & $\begin{array}{l}\text { Negative characterizations of } \\
\text { natural stimuli and associated } \\
\text { emotions: fear, repulsion ... }\end{array}$ & NA & 27.7 & - \\
\hline
\end{tabular}




\begin{tabular}{|c|c|c|c|c|}
\hline Content category & Meanings related to ... & Walks (\%) & $\begin{array}{l}\text { Images } \\
(\%)\end{array}$ & $\begin{array}{l}X^{2} \\
(d f=2)\end{array}$ \\
\hline Negative place & $\begin{array}{l}\text { Other negative spatial } \\
\text { characteristics: dirtiness, lack of } \\
\text { vegetation ... }\end{array}$ & 21.3 & NA & - \\
\hline Urban elements & $\begin{array}{l}\text { Urban or artificial elements } \\
\text { present in the natural } \\
\text { environment. }\end{array}$ & 51.1 & NA & - \\
\hline People & $\begin{array}{l}\text { Existence of other people in the } \\
\text { environment. }\end{array}$ & 12.8 & NA & - \\
\hline Activities & $\begin{array}{l}\text { Activities carried out during the } \\
\text { walk: walking, observing ... }\end{array}$ & 29.8 & NA & - \\
\hline $\begin{array}{l}\text { Enjoying contact } \\
\text { with nature }\end{array}$ & $\begin{array}{l}\text { Desire to have more contact with } \\
\text { real nature. }\end{array}$ & 31.9 & 33.6 & 0.04 \\
\hline $\begin{array}{l}\text { Living in natural } \\
\text { harmony }\end{array}$ & $\begin{array}{l}\text { Need to and benefits of living in } \\
\text { contact or harmony with nature, } \\
\text { in opposition to current urban } \\
\text { lifestyle. }\end{array}$ & 6.4 & 11.8 & 1.06 \\
\hline $\begin{array}{l}\text { Identification } \\
\text { with nature }\end{array}$ & $\begin{array}{l}\text { Personal attributions towards } \\
\text { natural stimuli that imply } \\
\text { identification with them. }\end{array}$ & 6.4 & 21.8 & $5.59 *$ \\
\hline Biospherism & $\begin{array}{l}\text { Value and respect for nature as } \\
\text { another form of life or entity. }\end{array}$ & 4.3 & 30.3 & $12.90 * *$ \\
\hline $\begin{array}{l}\text { Environmental } \\
\text { concern }\end{array}$ & $\begin{array}{l}\text { Concerns regarding the } \\
\text { degradation of the environment } \\
\text { and the need to protect it. }\end{array}$ & 10.6 & 32.8 & $8.47 * *$ \\
\hline $\begin{array}{l}\text { Reflections and } \\
\text { spirituality }\end{array}$ & $\begin{array}{l}\text { The capacity of nature to evoke } \\
\text { meta-personal reflections and } \\
\text { spiritual sensations. }\end{array}$ & 14.9 & 13.4 & 0.06 \\
\hline $\begin{array}{l}\text { Childhood } \\
\text { memories }\end{array}$ & Memories of childhood. & 38.3 & 19.3 & $6.52 *$ \\
\hline $\begin{array}{l}\text { Socio-family } \\
\text { memories }\end{array}$ & $\begin{array}{l}\text { Memories experienced with } \\
\text { family or people close to you. }\end{array}$ & 34 & 17.6 & $5.23 *$ \\
\hline $\begin{array}{l}\text { Memories of } \\
\text { nature }\end{array}$ & $\begin{array}{l}\text { Memories of other experiences in } \\
\text { natural environments. }\end{array}$ & 51.1 & 49.6 & 0.03 \\
\hline Nostalgia & $\begin{array}{l}\text { Emotions of loss or longing, in } \\
\text { relation to memories. }\end{array}$ & 14.9 & NA & - \\
\hline
\end{tabular}

Note: $\mathrm{NA}=$ not applicable; ${ }^{*} p<.05 ;{ }^{* *} p<.01$ 
Table 4. Frequencies and differences in the reporting of content categories between nature walks.

\begin{tabular}{|c|c|c|c|c|}
\hline Content category & $\begin{array}{l}\text { Spain: } \\
\text { high } \\
\text { immersion in } \\
\text { nature } \\
(\%)\end{array}$ & $\begin{array}{l}\text { France: } \\
\text { medium } \\
\text { immersion in } \\
\text { nature } \\
(\%)\end{array}$ & $\begin{array}{l}\text { Portugal: } \\
\text { low } \\
\text { immersion in } \\
\text { nature } \\
(\%)\end{array}$ & $X^{2}(d f=3)$ \\
\hline Nature & 42.9 & 37.5 & 47.1 & 0.31 \\
\hline Flora & 64.3 & 56.3 & 23.5 & $5.99 *$ \\
\hline Fauna & 57.1 & 31.3 & 5.9 & $9.67 * *$ \\
\hline Terrain and geology & 50 & 25 & 5.9 & $7.86^{*}$ \\
\hline Water elements & 78.6 & 56.3 & 11.8 & $14.63 * *$ \\
\hline Atmospheric elements & 57.1 & 6.3 & 5.9 & $15.31 * *$ \\
\hline Sensitive characteristics & 35.7 & 31.3 & 0 & $7.29 *$ \\
\hline Abundant nature & 71.4 & 37.5 & 35.3 & 4.87 \\
\hline Natural beauty & 35.7 & 37.5 & 47.1 & 0.5 \\
\hline Positive place & 21.4 & 37.5 & 29.4 & 0.92 \\
\hline Relaxation & 78.6 & 93.8 & 52.9 & $7.4 *$ \\
\hline Activation & 7.1 & 12.5 & 23.5 & 1.74 \\
\hline Well-being and fulfilment & 50 & 31.3 & 5.9 & $7.62 *$ \\
\hline Disconnection & 57.1 & 50 & 29.4 & 2.67 \\
\hline Negative place & 35.7 & 18.8 & 11.8 & 2.72 \\
\hline Urban elements & 7.1 & 87.5 & 52.9 & $19.33 * *$ \\
\hline People & 0 & 25 & 11.8 & 4.21 \\
\hline Activities & 14.3 & 18.8 & 52.9 & $6.9 *$ \\
\hline Enjoying contact with nature & 50 & 37.5 & 11.8 & 5.51 \\
\hline $\begin{array}{l}\text { Living in harmony with } \\
\text { nature }\end{array}$ & 21.4 & 0 & 0 & $7.55^{*}$ \\
\hline Identification with nature & 14.3 & 6.3 & 0 & 2.62 \\
\hline Biospherism & 7.1 & 0 & 5.9 & 1.11 \\
\hline Environmental concern & 28.6 & 6.3 & 0 & $7.08 *$ \\
\hline Reflections and spirituality & 21.4 & 12.5 & 11.8 & 0.68 \\
\hline Childhood memories & 64.3 & 31.3 & 23.5 & $5.91 *$ \\
\hline Socio-family memories & 71.4 & 37.5 & 0 & $17.57 * *$ \\
\hline Memories of nature & 78.6 & 56.3 & 23.5 & $9.57 * *$ \\
\hline Nostalgia & 14.3 & 12.5 & 17.6 & 0.18 \\
\hline
\end{tabular}

Note: ${ }^{*} p<.05 ; * * p<.01$ 